\title{
PHYSICAL AND WATER-QUALITY CHARACTERISTICS AFFECTING TROUT-SPAWNING HABITAT IN THE QUASHNET RIVER, CAPE COD, MASSACHUSETTS
}

By Yvonne Halpern Baevsky

U.S. GEOLOGICAL SURVEY

Water-Resources Investigations Report 91-4045

Prepared in cooperation with the

MASHPEE WATER DISTRICT

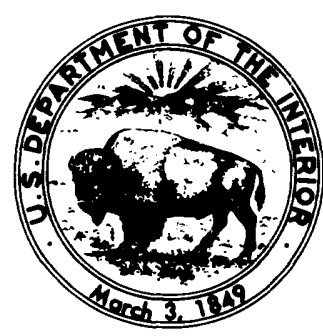

Marlborough, Massachusetts 1991 
U.S. DEPARTMENT OF THE INTERIOR

MANUEL LUJAN, JR., Secretary

U.S. GEOLOGICAL SURVEY

Dallas L. Peck, Director

For additional information, write to: Copies can be purchased from:

District Chief

Massachusetts Office

Water Resources Division

U.S. Geological Survey

28 Lord Rd., Suite 926

Marlborough, MA 01752
U.S. Geological Survey

Books and Open-File Reports Section

Federal Center, Bldg. 810

Box 25425

Denver, CO 80225 


\section{CONTENTS}

Page

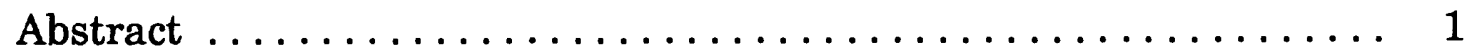

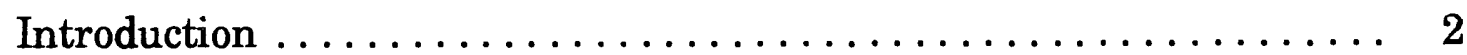

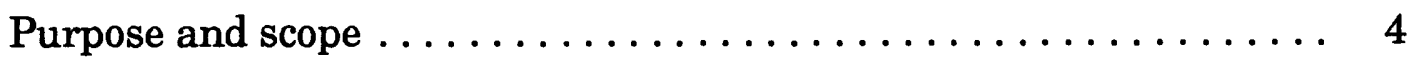

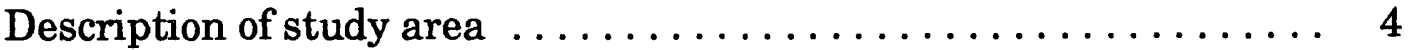

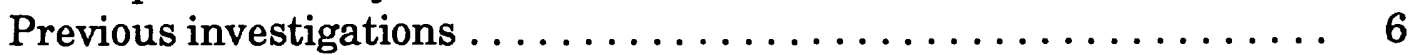

Study methods . . . . . . . . . . . .

Acknowledgments ........................ 7

Physical characteristics of the river $\ldots \ldots \ldots \ldots \ldots \ldots \ldots \ldots \ldots \ldots$

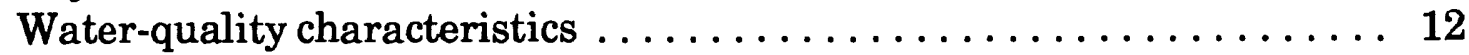

Temperature .............................. 12

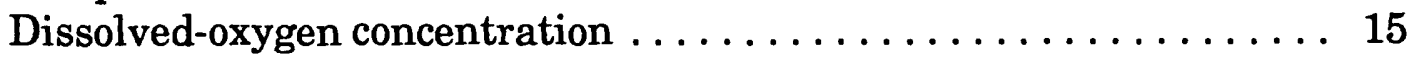

Hydrogen-ion concentration . . . . . . . . . . . . . . . . 16

Specific conductance ....................... 17

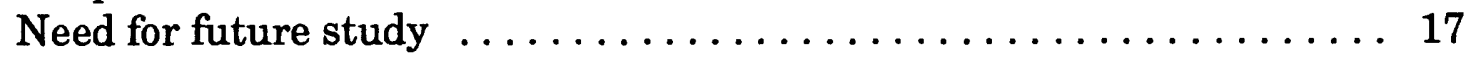

Summary and conclusions $\ldots \ldots \ldots \ldots \ldots \ldots \ldots \ldots \ldots \ldots \ldots \ldots$

References cited $\ldots \ldots \ldots \ldots \ldots \ldots \ldots \ldots \ldots \ldots \ldots \ldots \ldots$

\section{ILLUSTRATIONS}

Figure 1. Map showing location of data-collection and measurement sites along the Quashnet River ..... 3

2. Cross sections of the Quashnet River at Site 4, showing stream widths, depths, and velocities measured on October 26, and November 2, 1988; and June 29, 1989

3. Graphs showing precipitation measured at Hatchville, and discharge and river stage measured at the Quashnet River streamflow-gaging station 


\section{ILLUSTRATIONS (Continued)}

4. Graphs showing water temperature, dissolved-oxygen concentration, $\mathrm{pH}$, and specific conductance measured at six sites along the Quashnet River ........... 14

\section{TABLES}

Table1. Stream width, average depth, area, average velocity, and discharge measured at selected sites along the Quashnet River at various times, $1988-89$........

2. Temperature, dissolved-oxygen concentration, $\mathrm{pH}$, and specific conductance measured at selected sites along the Quashnet River at various times, $1988-89$. . . . 13 


\section{CONVERSION FACTORS, VERTICAL DATUM, AND ABBREVIATED WATER-QUALITY UNITS}

\begin{tabular}{|c|c|c|}
\hline Multiply & By & To obtain \\
\hline \multicolumn{3}{|c|}{ Length } \\
\hline \multirow[t]{2}{*}{ inch (in.) } & 25.4 & millimeter \\
\hline & 2.54 & centimeter \\
\hline foot $(\mathrm{ft})$ & 0.3048 & meter \\
\hline \multirow[t]{2}{*}{ mile (mi) } & 1.609 & kilometer \\
\hline & Velocity & \\
\hline \multirow[t]{2}{*}{ foot per second $(\mathrm{ft} / \mathrm{s})$} & 0.3048 & meter per second \\
\hline & Area & \\
\hline \multirow[t]{2}{*}{ square mile $\left(\mathrm{mi}^{2}\right)$} & 2.590 & square kilometer \\
\hline & \multicolumn{2}{|l|}{ Volume } \\
\hline cubic foot $\left(\mathrm{ft}^{3}\right)$ & 0.02832 & cubic meter \\
\hline gallon (gal) & 3.785 & liter \\
\hline \multicolumn{3}{|c|}{ Flow } \\
\hline cubic foot per second $\left(\mathrm{ft}^{3} / \mathrm{s}\right)$ & 0.02832 & $\begin{array}{l}\text { cubic meter per } \\
\text { second }\end{array}$ \\
\hline \multicolumn{3}{|c|}{ Temperature } \\
\hline \multicolumn{3}{|c|}{ degrees Celsius $\left({ }^{\circ} \mathrm{C}\right)=\left[\right.$ degrees Fahrenheit $\left.\left({ }^{\circ} \mathrm{F}\right)-32\right] \times 0.555$} \\
\hline \multicolumn{3}{|c|}{ Specific Conductance } \\
\hline \multicolumn{3}{|c|}{ microsiemens per centimeter at 25 degrees Celsius $(\mu \mathrm{S} / \mathrm{cm})$} \\
\hline \multicolumn{3}{|c|}{ Other abbreviations used in this report } \\
\hline
\end{tabular}

Sea Level: In this report, "sea level" refers to the National Geodetic Vertical Datum of 1929--a geodetic datum derived from a general adjustment of the first-order level nets of the United States and Canada, formerly called Sea Level Datum of 1929. 


\title{
Physical and Water-Quality Characteristics Affecting Trout-Spawning Habitat in the Quashnet River, Cape Cod, Massachusetts
}

\author{
by Yvonne Halpern Baevsky
}

\begin{abstract}
This report presents the results of a reconnaissance study of the physical and water-quality characteristics of the Quashnet River by the U.S. Geological Survey, in cooperation with the Mashpee Water District, in 1988 and 1989. The Quashnet River, a ground-water sustained, trout-spawning stream on Cape Cod, has been designated an Area of Critical Environmental Concern by the Commonwealth of Massachusetts, because of the possible effects of current and projected population growth in the watershed. The concerns are that the development of new wells for water supply may deplete streamflow, which may adversely affect trout-spawning activity and that contamination of ground water by septic-system and agricultural wastes may degrade stream-water quality, which may adversely affect trout-spawning.

Hydrologic and water-quality conditions in a stream determine its viability as a trout habitat. Previous research has identified the importance of groundwater discharge in maintaining the characteristics of water temperature, $p H$, and dissolved-oxygen concentration within the limits which are critical to successful development of trout embryo.

Selected physical characteristics of the river--stream width, depth, and velocity--were measured at up to five sites at five different times in the annual hydrologic cycle; selected water-quality characteristics of the river--temperature, dissolved-oxygen concentration, $\mathrm{pH}$, and specific conductance--were measured concurrently.
\end{abstract}


The Quashnet River is normally sustained by ground-water discharge at all but the highest flow rates, which result from direct runoff of precipitation or the release of water stored in cranberry bogs. During base flow, when all the streamflow is from storage, about one-third of the streamflow below the spawning reach, in the reach from the estuary to the spawning grounds that trout must travel through, is derived from ground-water discharge. The autumn spawning run of 1988 was found to coincide with the release of water from a cranberry bog, following harvest. During a 1- to 2-day interval when the spawning activity of the sea-run brown trout peaked, velocities reached 1.8 feet per second and the discharge peaked at 32 cubic feet per second at the center of the spawning area.

In the spawning reach, during the spawning period of 1988, temperatures ranged from 10 to 11 degrees Celsius. Dissolved-oxygen concentrations ranged from 9.3 to 12.6 milligrams per liter. The $p H$ ranged from 5.96 to 6.38 units and specific conductance ranged from 54 to 66 microsiemens per centimeter at 25 degrees Celsius.

The effects of proposed ground-water withdrawals on the volume of streamflow in the river need to be assessed spatially and temporally in terms of the locations and reduction of ground-water discharge to the Quashnet River. The effects of proposed withdrawals on the spawning reaches could be estimated with a digital ground-water flow model calibrated to simulate ground-water/stream interaction. The hydrologic and water-quality information obtained in this study of the Quashnet River establishes an initial data base for research on the interaction of hydrology and aquatic biology in an environment where fish-embryo development is directly affected by hydrologic conditions.

\section{INTRODUCTION}

The Quashnet River, an important trout-spawning habitat and popular stream for trout fishing, is located on Cape Cod--one of the fastest growing areas in New England--in the towns of Mashpee and Falmouth, Massachusetts (fig. 1). Development associated with current and projected population growth is placing increasing stresses on the natural resources of the area. This development raised concerns that the development of new wells for water supply may deplete streamflow to trout-spawning areas, and that contamination of ground water by septic-system and agricultural wastes may degrade stream-water quality. Environmental planners and fisheries managers need to know the physical and water-quality characteristics of the Quashnet River; an understanding of the present conditions that make the fishery viable can be used to develop management strategies to minimize future harm to the trout habitat. 


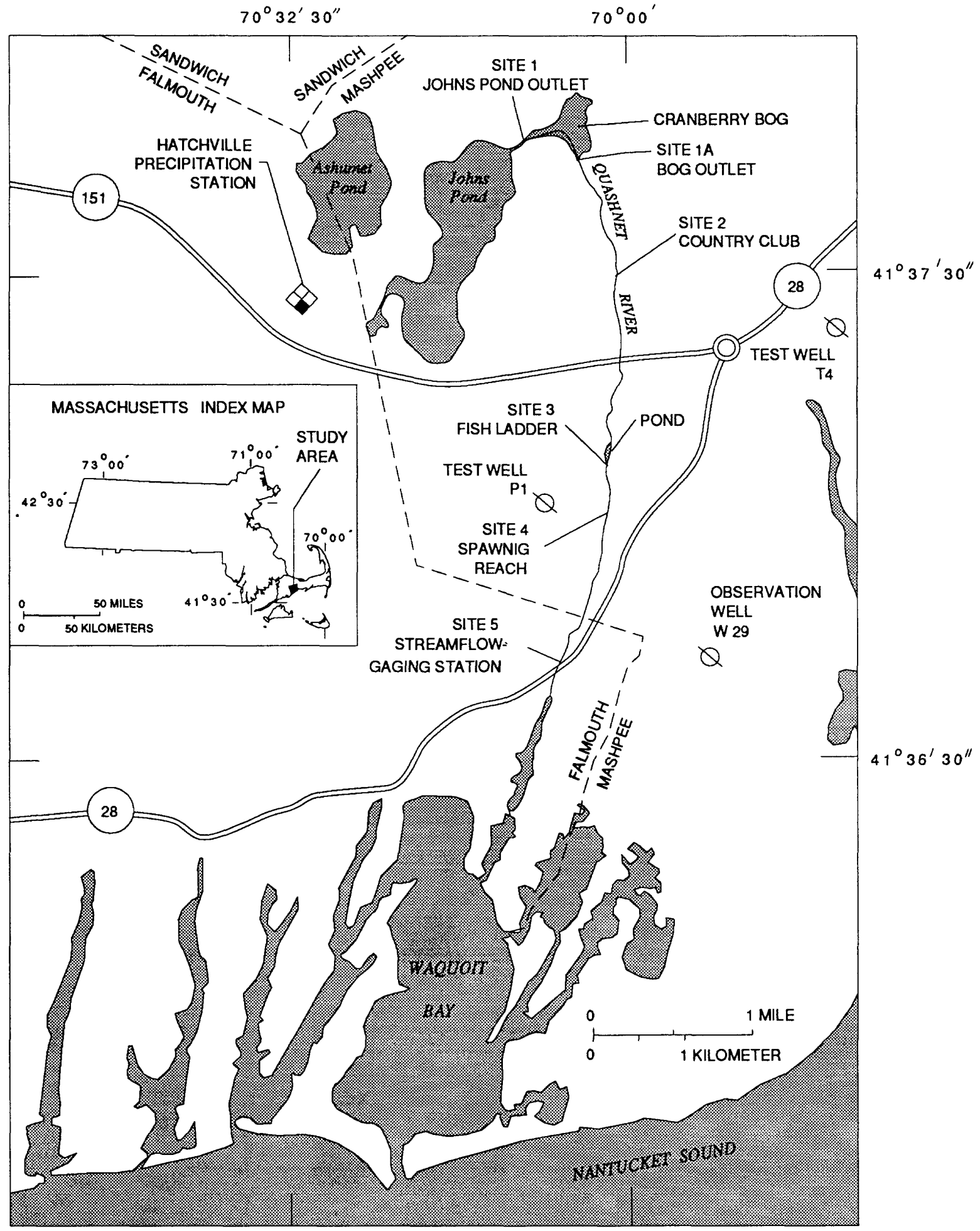

Figure 1.--Location of data-collection and measurement sites along the Quashnet River. 
The information presented in this report was developed by the U.S. Geological Survey in cooperation with the Mashpee Water District and with the advice and guidance of the Massachusetts Division of Fisheries and Wildlife. This information is needed for planning watershed management in the Quashnet River basin and wherever streams sustained by ground water support the spawning of sea-run brown trout and other salmonid fish.

\section{Purpose and Scope}

The purposes of this report are to (1) describe the physical and water-quality characteristics of the Quashnet River, including the trout-spawning areas; and (2) indicate possible approaches for additional study that would provide information necessary for effective management of the trout fishery under the stresses of ground-water withdrawal and waste-water discharge.

A variety of physical, hydrologic, and water-quality characteristics were examined as part of a reconnaissance study to document the conditions that make the river a productive trout fishery. Measurements were made during spawning in October and November 1988 and in June 1989. The measurements represent high- and low-flow conditions and demonstrate the effects of ponding and releasing water from upstream cranberry-harvesting operations on the trout-spawning area. Stream-channel characteristics measured under high-and low-flow conditions in the spawning area were width, depth, cross-sectional area, and velocity. Water-quality characteristics measured concurrently were temperature, dissolved-oxygen concentration, $\mathrm{pH}$ and specific conductance. These data are used in planning additional work on ground-water flow and ground-water/stream interaction in the Quashnet River basin.

\section{Description of Study Area}

The Quashnet River drainage basin encompasses approximately $5 \mathrm{mi}^{2}$ in Mashpee and Falmouth, Massachusetts. The Quashnet river drains into Waquoit Bay, an estuary of Nantucket Sound (fig. 1). The river originates at the outlet of Johns Pond, which is formed from the coalescing of two kettle hole ponds as much as $62 \mathrm{ft}$ deep in the Mashpee outwash plain. Outflow from the pond into the river can be regulated by a gate-controlled spillway which consists of a channel, a flume, and a sluiceway capable of drawing down the level of Johns Pond to $4 \mathrm{ft}$ below its average elevation (McVoy, 1982); the average elevation of Johns Pond is $38 \mathrm{ft}$ above sea level. The spillway was constructed to regulate flow to the cranberry bogs for irrigation, and to flood the bogs for frost protection and harvesting. From the 
spillway, the river enters cranberry bogs, (fig. 1) flows east for $0.4 \mathrm{mi}$ and then flows to the south for 3.5 mi past a country club and golf course, and through abandoned bogs, several of which have been restored to natural habitats, before emptying into Waquoit Bay. The primary trout-spawning reach is from 2.2 to $3.3 \mathrm{mi}$ downstream from the spillway.

McLarney (1988) has compiled a history of the Quashnet River restoration project since the abandonment of many of the cranberry bogs that filled the floodplain and choked the river channel. The Cape Cod chapter of Trout Unlimited has coordinated the restoration of the Quashnet River. As a result of more than 14,000 volunteer hours, the stream channel has been unclogged, and native vegetation has returned to the Quashnet flood plain and stream channel, in what is now the 1-mi-long spawning reach between Route 28 and a fish ladder (fig. 1). This 1-mi-long reach receives constanttemperature ground-water discharge through a sand-and-gravel bottom, which is favored by sea-run brown trout for successful spawning.

Because the population has doubled since 1970, undeveloped lands on Cape Cod have given way to an increasingly residential and suburban environment. Much of the Quashnet River basin is still undeveloped forest, particularly the area surrounding the spawning reach. However, increased developmental pressures in the Quashnet River basin are reflected in three large residential developments and a number of small subdivisions that are scheduled for construction. One proposed development included approximately 570 residences on 110 acres on the banks of the river. To protect the river, the Commonwealth of Massachusetts purchased 361 acres of land along the river, thereby limiting this housing development to 185 units without river frontage. The Quashnet River drains into Waquoit Bay which was identified in 1988 as a National Estuarine Research Reserve by the National Oceanic and Atmospheric Administration and the Massachusetts Department of Environmental Management (June Cradick, National Oceanographic and Atmospheric Administration, oral commun., 1991). These agencies are developing an ecosystem model to predict the effects of land use on the water quality and aquatic resources of Waquoit Bay. The bay and the trout-spawning reach of the Quashnet River have been designated an Area of Critical Environmental Concern by the Commonwealth of Massachusetts (Steve Bliven, 1989, p.II32-39). Massachusetts has designated the Quashnet River as Class B--a river used for protection and propagation of fish, other aquatic life and wildlife; and for primary- and secondary-contact recreation (Division of Water Pollution Control, 1988).

The Quashnet River basin is underlain by outwash deposits of stratified sand and gravel with local silt and clay layers; these deposits overlie granitic basement rock at a depth of about $420 \mathrm{ft}$ below sea level (LeBlanc and 
others, 1986). The outwash deposits are generally very permeable and form an important water-table aquifer. Twenty-four-in. diameter, 10-ft-longscreened wells developed in these deposits commonly yield 25- to 1000-gal per minute (LeBlanc and others, 1986).

The average annual precipitation in the study area is $44 \mathrm{in}$. The precipitation occurs fairly uniformly throughout the year, but varies from year to year. It is estimated that 37 to 45 percent of the total precipitation reaches the water table (Leblanc and others, 1986). Ground-water recharge occurs mainly in winter during the nongrowing season because most precipitation is returned to the atmosphere as evapotranspiration during the May-to-September growing season (LeBlanc and others, 1986). Summers are humid and warm and the winter climate is mild to temperate, with some snow and ice.

\section{Previous Investigations}

The general hydrology of Cape Cod was initially described by Strahler (1972). LeBlanc and others (1986) described the hydrology and groundwater availability, mapped the water table of five freshwater lenses, and reported on the ground-water-flow system, saltwater-freshwater boundaries, recharge to the aquifer, and discharge to streams. Ryan (1980) summarized hydrologic properties of the Cape Cod aquifer system, public water-supply systems, and potential sources of ground-water contamination. Digital models of ground-water flow were constructed by Guswa and LeBlanc (1985). Frimpter and Gay (1979) presented the general chemical quality of ground water on Cape Cod. Persky (1986) discussed the effects of development on ground-water quality.

Several previous investigations provide guidelines for the water quality needed for a viable fish habitat. U.S. Environmental Protection Agency (USEPA) (1972) provides information on the requirements of oxygen and other constituents necessary for successful spawning of salmonid fishes. USEPA (1986) reports the lowest observed levels for chronic toxicity of freshwater aquatic life. The effects of temperature on salmonid spawning is outlined by Meisner and others (1988).

\section{Study Methods}

Measurements of stream discharge were made at four sites by conventional current-meter methods at 20 or more stations across each section, and at one site with a portable Parshall flume (Rantz and others, 1982.) The other 
physical characteristics of the river--width, depth, area, and velocity--were obtained as part of each discharge measurement.

Water-quality characteristics of the Quashnet River were measured at six sites. Initially, measurements were made along the discharge-measurement section with a combined specific conductance and water temperature probe to determine their variability, both vertically and horizontally, across the stream's profile. No significant variation of these properties was detected in any of the profiling; therefore, water temperature, specific conductance, and $\mathrm{pH}$ measurements reported here were obtained by submerging probes from portable field instruments in mid-channel at mid-depth. These probes were calibrated in the field to the ranges encountered. Concentrations of dissolved oxygen also were determined using a portable meter in the field by the air-calibration method recommended by the instrument manufacturer.

\section{Acknowledgments}

The author gratefully acknowledges the assistance provided by Nathan S. Ellis of the Mashpee Water District. The author thanks Joseph D. Bergin of the Commonwealth of Massachusetts Division of Fisheries and Wildlife for providing information on the life cycle and habitat of the sea-run brown trout and for identifying spawning reaches of the Quashnet River.

\section{PHYSICAL CHARACTERISTICS OF THE RIVER}

The major hydrologic factors affecting fish habitat are flow volume, depth, and velocity. The pattern of changes in these factors affects spawning success because the timing of favorable hydrologic conditions must coincide with favorable physical and chemical conditions of the water and the reproductive behavior of fish. The spawning of sea-run brown trout is, in part, controlled by water velocity and depth. Sufficient depth is required to allow space for fish to pass upstream to spawn during autumn migration. Flow velocities are important because the sea-run brown trout require a velocity of at least $1 \mathrm{ft} / \mathrm{s}$ in spawning areas because, at this velocity, the streambed will tend to be composed of sand and gravel--which is needed for the construction of fish-egg nests (redds)--and a velocity of no more than $0.5 \mathrm{ft} / \mathrm{s}$ in nearby areas to provide resting areas for the migrating and developing fish (Bergin, J.D., Massachusetts Division of Fisheries and Wildlife, oral commun., 1988).

Trout spawn in areas where ground water discharges to bathe the developing embryos. Low water velocities through the streambed could allow fine- 
grained sediments to deposit in spawning areas, reducing the streambed permeability and preventing the exchange of oxygen between the embryos and intragranular water. In order to prevent the deposition of fine-grained detritus and to remove potentially toxic waste products released by the developing embryos, it is necessary to maintain a sufficient water velocity within the streambed (Hoffman and Scoppettone, 1988).

Five sites along the Quashnet River were selected for study (fig. 1). At Site 1, Johns Pond outlet, a flume was inserted in the beach sand $5 \mathrm{ft}$ upstream from the manmade spillway. At Site 2, the Country Club, measurements were made in a sand streambed with submerged reeds. Site 3 , the Fish Ladder, is $15 \mathrm{ft}$ downstream from a concrete fish ladder. Here, the streambed consists of sand and gravel that is suitable for the construction of redds. Site 4 is in the middle of the spawning reach, where the streambed is composed of gravel and small cobbles. Site 5, the Streamflow-Gaging Station, is adjacent to a continuous streamflow-gaging station and is on the upstream side of a bridge. Here, the streambed is composed of sand and small and medium cobbles.

Stream widths, depths, cross-sectional areas, velocities, and discharge measurements are presented in table 1 along with locality and date of measurement. Figure 2 shows how stream width, depths, cross-sectional area, and velocity change with varying flow conditions at a site within the spawning reach (Site 4). Figure 2a illustrates a cross section of the stream at Site 4 on October 26, 1988, during low flow when other streams in the region were at 80-percent flow duration. Water discharge was controlled for cranberry harvest, so that no measurable flow was observed entering the river from the bog (Site 1a, fig. 1). At Site 4, in the middle of the spawning area, the maximum depth was $0.78 \mathrm{ft}$ and the discharge was $4.5 \mathrm{ft}^{3} / \mathrm{s}$. Figure $2 \mathrm{~b}$ illustrates a cross-section of the stream at Site 4 on November 2 nd, during the 1988 high-flow spawning event. This high-flow event was entirely caused by the rapid release of water used for the upstream cranberry-bog harvest over a 1- to 2-day interval. The spawning run of the sea-run brown trout was observed by fishery biologists to coincide with the release of water from the cranberry-bog harvest (Bergin, J.D., Massachusetts Division of Fisheries and Wildlife, oral commun., 1988). The maximum depth was $1.90 \mathrm{ft}$ and the discharge was $32 \mathrm{ft}^{3} / \mathrm{s}$. A cross-section of the stream at Site 4 on June 29,1989 , is illustrated in figure $2 c$. The maximum depth of this section was $1.48 \mathrm{ft}$ and the discharge was $11 \mathrm{ft}^{3} / \mathrm{s}$.

In the spawning reach (Sites 3 and 4), the size of the bottom material ranged from sand and gravel to small cobbles, as is needed for spawning success by allowing ground water to discharge through the redds. During baseflow periods not affected by storage and releases from the cranberry bogs, 
about a 3- to $4-\mathrm{ft}^{3} / \mathrm{s}$ increase of flow (an increase of about 50 percent) between the fish ladder and the streamflow-gaging station (1.1 mi) is attributed to ground-water discharge (table 1). Also important to spawning success, is the presence of covered areas in the stream within $50 \mathrm{ft}$ of the spawning site (Bergin, J.D., Massachusetts Division of Fisheries and Wildlife, oral commun., 1988). These covered areas were constructed by the Cape Cod Chapter of Trout Unlimited to control water temperature and to provide larvae and juveniles protection from predation. Trees were planted to shade the river, thereby controlling the growth of reeds.

Comparison of the precipitation record (U.S. Department of Commerce, 1988-89) from Hatchville, Massachusetts, 1/4 mi south of Ashumet Pond (fig. 1), with the stream-discharge record from the Quashnet River streamflow-gaging station shows that many but not all of the high flows were caused by precipitation (fig. 3). For example, the high flows of April,

Table 1.--Stream width, average depth, area, average velocity, and discharge measured at selected sites along the Quashnet River, 1988-89

$\left[-\right.$, no data; mi, miles; $\mathrm{ft}$, foot; $\mathrm{ft}^{2}$, square foot; ft/s, foot per second; $\mathrm{tt}^{3} / \mathrm{s}$, cubic foot per second]

\begin{tabular}{lccccccc}
\hline $\begin{array}{l}\text { Site and } \\
\text { date }\end{array}$ & $\begin{array}{c}\text { River mile } \\
(\mathrm{mi})\end{array}$ & $\begin{array}{c}\text { Width } \\
(\mathrm{ft})\end{array}$ & $\begin{array}{c}\text { Average } \\
\text { depth } \\
(\mathrm{ft})\end{array}$ & $\begin{array}{c}\text { Area } \\
\left(\mathrm{ft}^{3}\right)\end{array}$ & $\begin{array}{c}\text { Average } \\
\text { velocity } \\
(\mathrm{ft} / \mathrm{s})\end{array}$ & $\begin{array}{c}\text { Discharge } \\
\left(\mathrm{ft}^{3} / \mathrm{s}\right)\end{array}$ \\
\hline Site 1: & Johns Pond & & & & & & \\
& $\begin{array}{c}10-26-88 \\
11-02-88\end{array}$ & 0 & -- & -- & -- & - & no flow \\
& $06-29-89$ & & -- & -- & -- & - & no flow \\
& Country & -- & -- & -- & -- & 0.1
\end{tabular}

Site 2: Country club

$\begin{array}{lllllll}11-02-88 & 1.2 & 15.0 & 2.3 & 35 & 0.86 & 30\end{array}$

Site 3: $\quad$ Fish ladder

$\begin{array}{lllllll}10-07-88 & 2.2 & 7.7 & .78 & 6.0 & 1.1 & 6.6\end{array}$

Slte 4: Spawning reach

$\begin{array}{rrrcccr}10-26-88 & 2.5 & 8.4 & .57 & 4.8 & .92 & 4 \\ 11-02-88 & & 12.0 & 1.5 & 17.9 & 1.8 & 32 \\ 06-29-89 & & 10.6 & .94 & 10 & 1.1 & 11\end{array}$

Site 5: Streamflow-gaging station

$\begin{array}{lrrrrrr}10-07-88 & 3.3 & 8.3 & .78 & 6.5 & 1.6 & 10 \\ 10-18-88 & & 11.6 & .84 & 9.7 & 1.1 & 11 \\ 10-26-88 & & 11.0 & .85 & 9.4 & .81 & 7.6 \\ 11-02-88 & & 11.0 & 1.5 & 17 & 2.1 & 36 \\ 06-29-89 & & 9.4 & 1.1 & 10 & 1.5 & 15\end{array}$

1 River mile refers to the number of miles downstream from the river's origin at Johns Pond. 


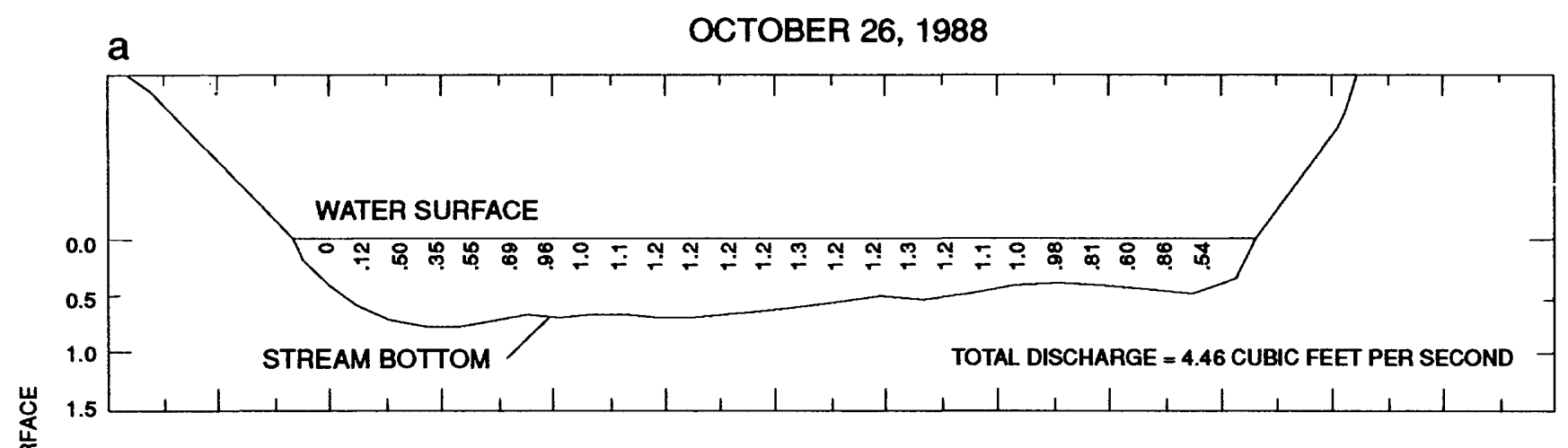

NOVEMBER 2, 1988

b

NOVEMBER 2,1988

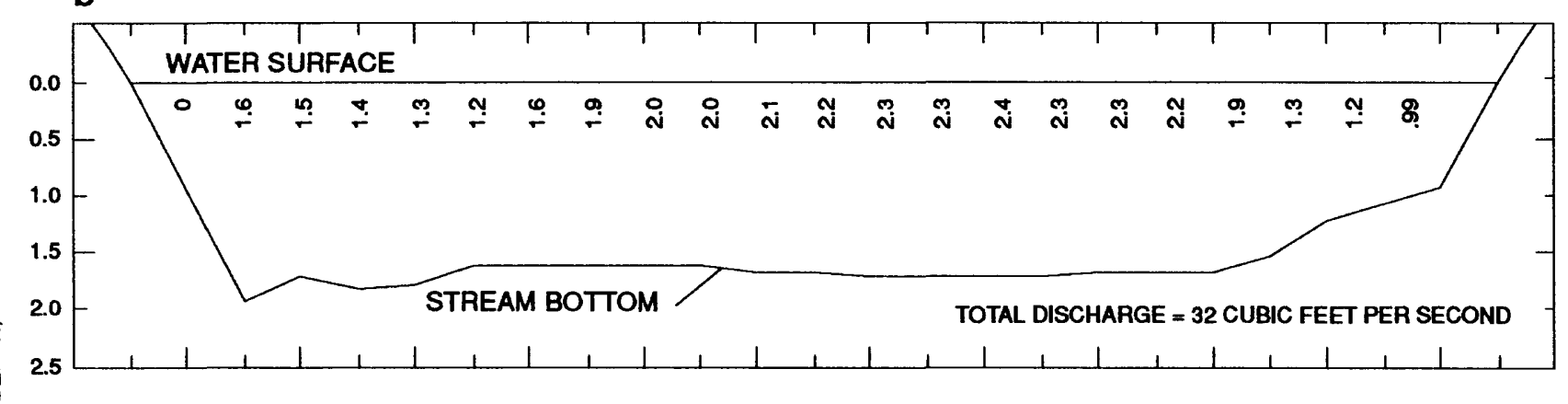

JUNE 29, 1989

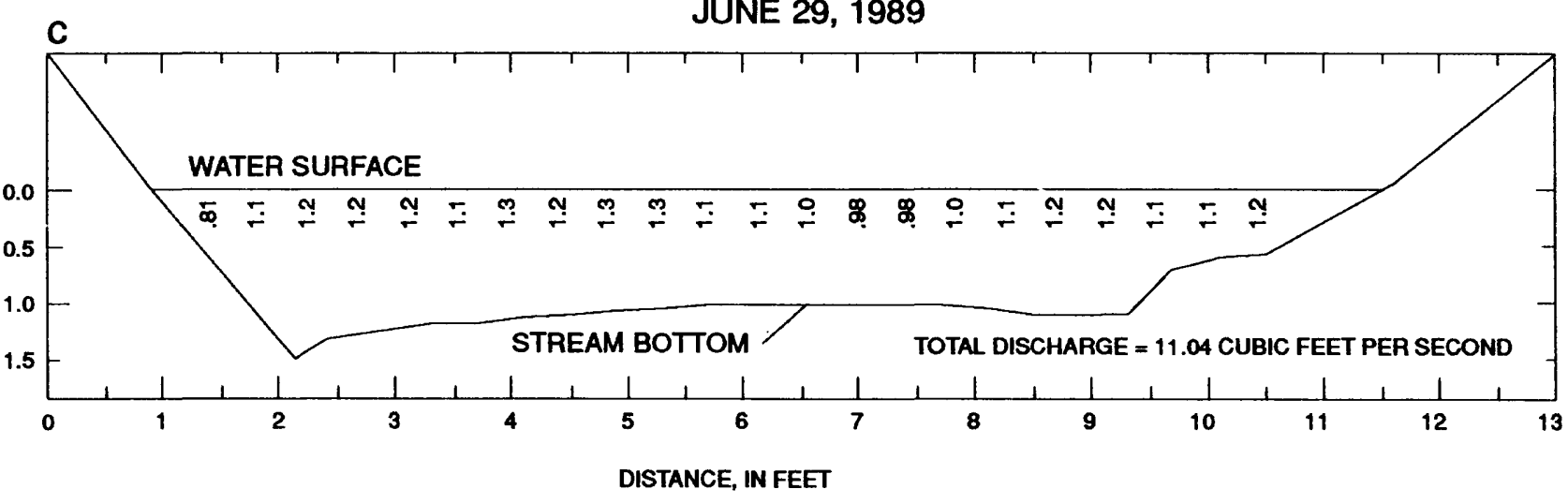

EXPLANATION

= STREAM VELOCITY, IN FEET PER SECOND

Figure 2.--Cross sections of the Quashnet River at Site 4, showing stream widths, depths, and velocities measured on October 26, and November 2, 1988; and June 29, 1989. 


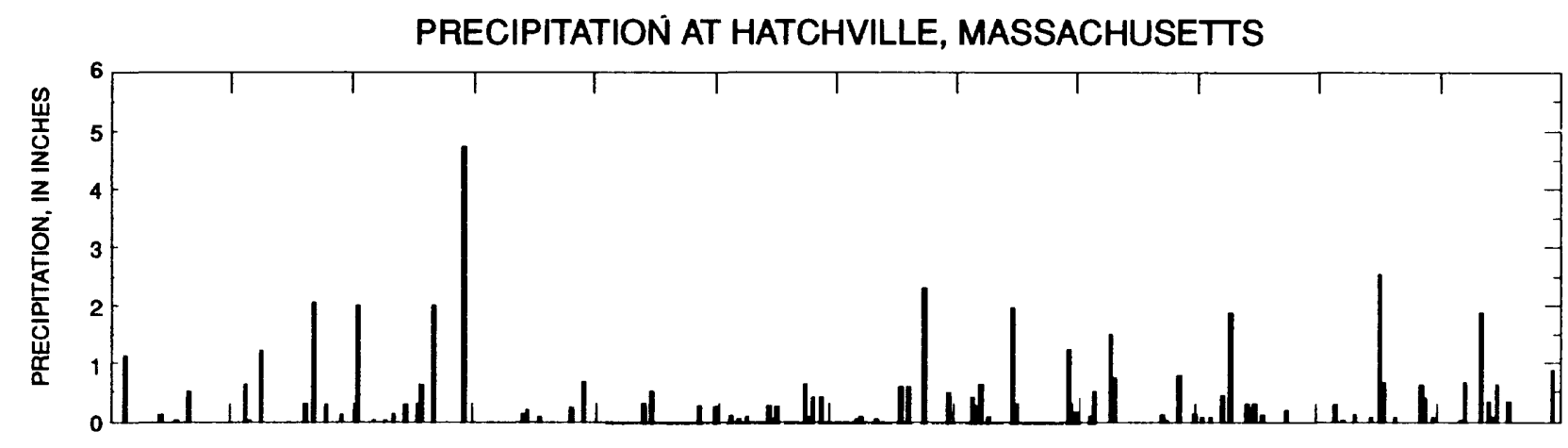

DISCHARGE AT STREAMFLOW-GAGING STATION (SITE 5)

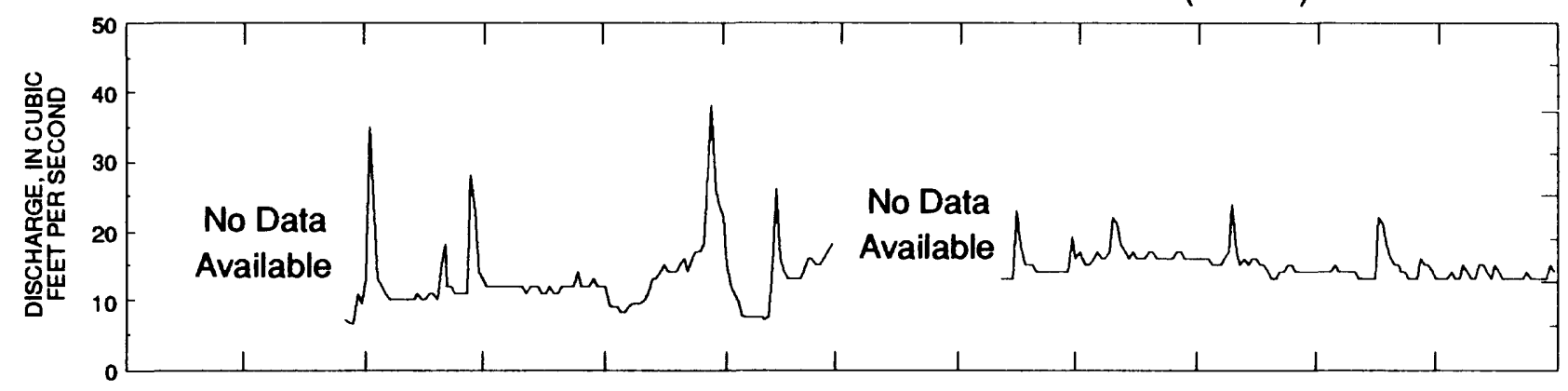

RIVER STAGE AT STREAMFLOW-GAGING STATION (SITE 5)

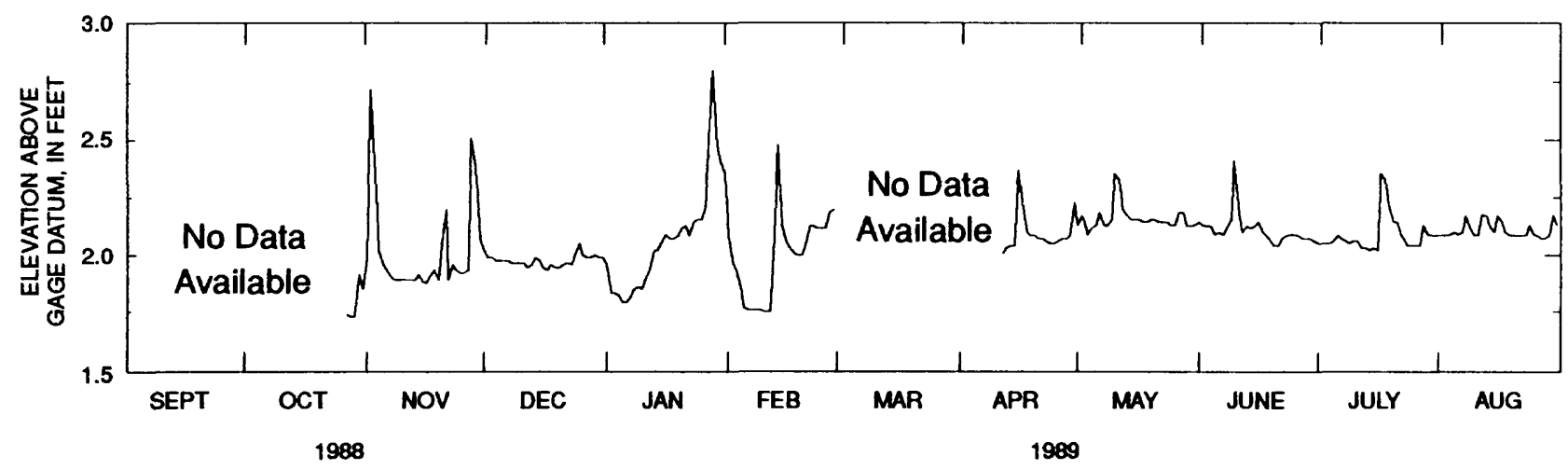

Figure 3.--Precipitation measured at Hatchville, and discharge and river stage measured at the Quashnet River streamflow-gaging station. 
May, June, and July 1989 are clearly related to precipitation events. However, the high flows of January 27-31 and February 14, 1989 were largely the result of rapid releases of water stored in the bog for protection of the cranberry plants from frost. On November 2-3, 1988, the recorded spawning period, the high flows resulted from the rapid release of stored water following the cranberry-bog harvest and precipitation on November 1.

\section{WATER-QUALITY CHARACTERISTICS}

\section{Temperature}

Sea-run brown trout and other anadromous salmonid fish are sensitive to differences in water temperature between the various regions they inhabit, and these differences may adversely affect particular phases of the reproductive and development cycles. Ground-water discharge may play an important role by stabilizing the thermal environment of salmonid fishes. Shallow ground water has a nearly constant temperature, which is the same as the mean air temperature. In the winter, when air temperature tends to cool the stream, the discharging ground water warms the surface water; in the summer, the discharging ground water cools the warmer surface water.

The temperature of the microhabitat surrounding trout egg nests needs to be between 5 and $13.3^{\circ} \mathrm{C}$ for successful incubation (Leitritz and Lewis, 1976). During the winter incubation, when the ground-water temperature is warmer than the air temperature, the ground water that discharges through the streambed protects the salmonid eggs by keeping the temperature within the optimal range and by inhibiting the formation of anchor ice, which has been recognized as increasing the risk of mortality (Meisner and others, 1988). Discharging ground water tends to stabilize the thermal regime of the stream and therefore, temperature differences between the spawning and development habitats are small. This may prevent premature hatching when the young fry are released into the nursery areas too early to ensure their survival in still-unproductive, cold waters.

Ground-water discharge also may ensure that the stream-water temperature falls within the optimal range of 12 to $18{ }^{\circ} \mathrm{C}$ for mature brown trout. Especially during the summer, ground-water discharge to the lower reaches of the stream may produce the proper thermal habitat, thereby affecting the size of the trout population (Meisner and others, 1988).

A significant difference in stream-water temperature was observed in the Quashnet River between the autumn sampling season and the June sampling (table 2, fig. 4a). Stream-water temperatures along the stream during 
Table 2.-Temperature, dissolved-oxygen concentration, $p H$, and specific conductance measured at selected sites along the Quashnet River, 1988-89

[mi, miles; ${ }^{\circ} \mathrm{C}$, degrees Celsius; $\mathrm{mg} / \mathrm{L}$, milligrams per liter; $\mu \mathrm{S} / \mathrm{cm}$, microsiemens per centimeter]

\begin{tabular}{|c|c|c|c|c|c|c|}
\hline $\begin{array}{l}\text { Site and } \\
\text { date }\end{array}$ & & $\begin{array}{l}\text { River mile } \\
\quad \text { (mi) }\end{array}$ & $\begin{array}{c}\text { Temperature } \\
\left({ }^{\circ} \mathrm{C}\right)\end{array}$ & $\mathrm{pH}$ & $\begin{array}{c}\text { Dissolved } \\
\text { oxygen } \\
\text { (mg/L) }\end{array}$ & $\begin{array}{l}\text { Specific } \\
\text { conductance } \\
\mu \mathrm{S} / \mathrm{cm}\end{array}$ \\
\hline \multirow[t]{2}{*}{ Site 1: } & Johns Pond & & & & & \\
\hline & $06-29-89$ & 0 & 26.3 & 7.55 & 8.4 & 82 \\
\hline \multirow[t]{2}{*}{ Site 1A: } & Bog outlet & & & & & \\
\hline & $10-26-88$ & .4 & 9.8 & 5.46 & 7.8 & 66 \\
\hline \multirow[t]{2}{*}{ Site 2: } & Country club & & & & & \\
\hline & $11-02-88$ & 1.2 & 10.2 & 5.8 & 7.9 & 55 \\
\hline \multirow[t]{2}{*}{ Site 3: } & Fish ladder & & & & & \\
\hline & $10-07-88$ & 2.2 & 11.4 & 6.38 & 12.6 & 60 \\
\hline \multirow[t]{2}{*}{ Site 4: } & Spawning rea & & & & & \\
\hline & $\begin{array}{l}10-26-88 \\
11-02-88 \\
06-29-89\end{array}$ & 2.5 & $\begin{array}{l}10.2 \\
10.0 \\
17.9\end{array}$ & $\begin{array}{l}5.96 \\
6.11 \\
6.8\end{array}$ & $\begin{array}{r}10.4 \\
10.2 \\
9.3\end{array}$ & $\begin{array}{l}66 \\
54 \\
73\end{array}$ \\
\hline \multirow[t]{2}{*}{ Site 5: } & Streamflow-g & ing station & & & & \\
\hline & $\begin{array}{c}10-03-88 \\
10-26-88 \\
11-02-88 \\
06-29-89\end{array}$ & 3.3 & $\begin{array}{r}11.8 \\
10.3 \\
9.8 \\
18.5\end{array}$ & $\begin{array}{l}6.33 \\
6.08 \\
6.15 \\
6.64\end{array}$ & $\begin{array}{r}11.9 \\
9.6 \\
10.4 \\
9.2\end{array}$ & $\begin{array}{l}62 \\
66 \\
56 \\
72\end{array}$ \\
\hline
\end{tabular}

the autumn sampling remained between 10 and $11{ }^{\circ} \mathrm{C}$. The measurements made in June 1989 show the seasonal effects of air temperature. The temperature of the water entering the river from the pond (Site 1) was $26.3^{\circ} \mathrm{C}$ because of exchange of heat from the warm atmosphere into the pond water. The air temperature had little effect on downstream reaches where groundwater discharge to the stream lowers the overall water temperature; in the spawning reach (Site 4), the stream-water temperature was $17.9{ }^{\circ} \mathrm{C}$ and the temperature of the ground water discharging to the stream was $14^{\circ} \mathrm{C}$. Farther downstream, a slight increase in temperature was observed at the streamflow-gaging station (Site 5) where the water temperature reached $18.5^{\circ} \mathrm{C}$, possibly because of the warm air temperature. 

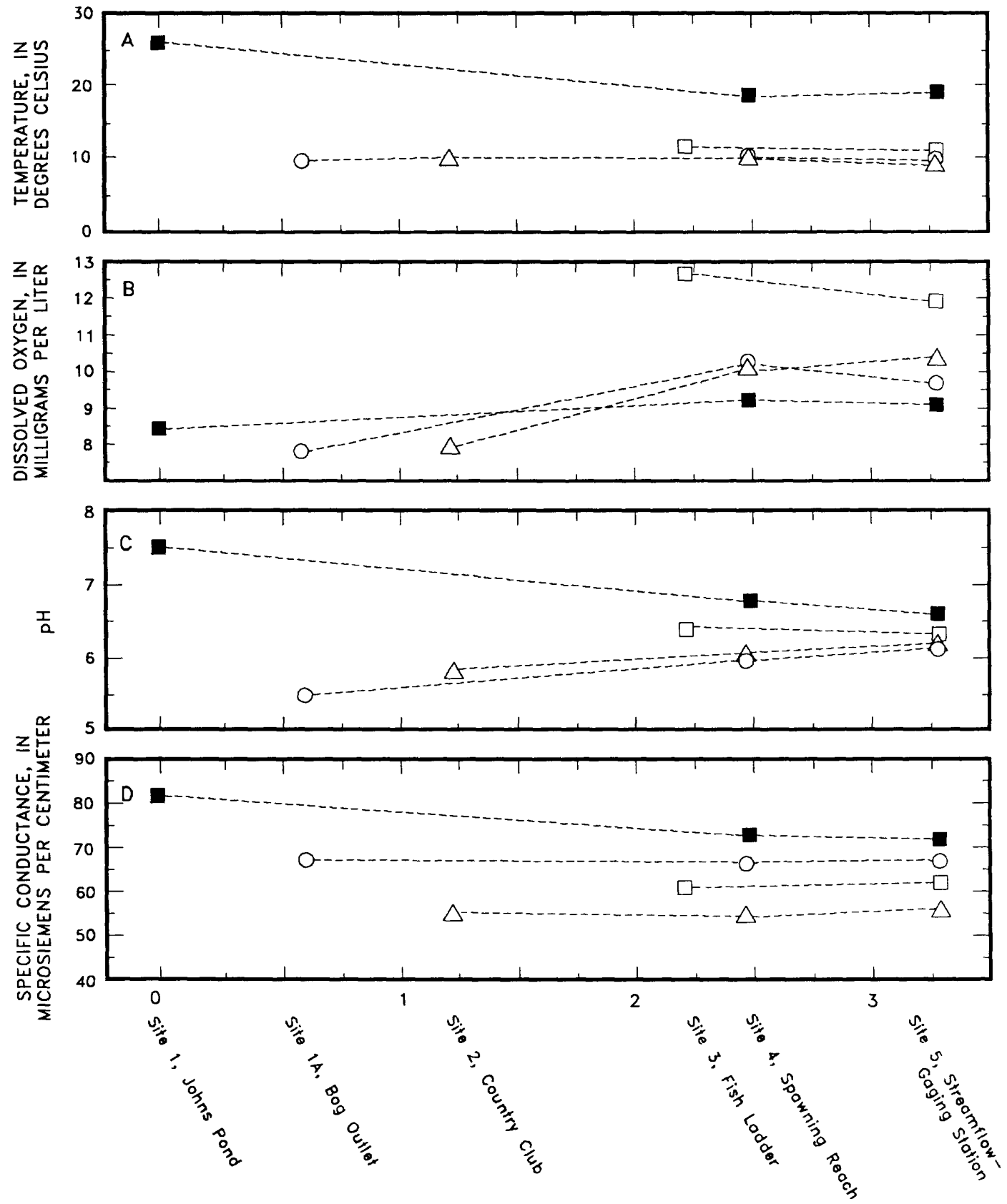

DISTANCE DOWNSTREAM, IN MILES

EXPLANATION

$$
\begin{array}{cc}
\ldots-\cdots & 10 / 7 / 88 \\
\ldots 0 & 10 / 26 / 88 \\
\ldots \triangle-1 & 11 / 2 / 88 \\
\ldots-\cdots & 6 / 29 / 89
\end{array}
$$

Figure 4.--Water temperature, dissolved-oxygen concentration, $\mathrm{pH}$, and specific conductance measured at six sites along the Quashnet River. 


\section{Dissolved-Oxygen Concentration}

At the redds, the concentration of dissolved oxygen in the intragranular water of the streambed is critical for the survival and development of the trout eggs. Any reduction in the concentration of dissolved oxygen can adversely affect the survival and growth of the eggs and larvae and thereby diminish spawning success (Meisner and others, 1988; U.S. Environmental Protection Agency, 1972). In ground-water-sustained streams, dissolved oxygen in the intragranular water is controlled by the mixing of stream and discharging ground waters of different temperatures and dissolved-oxygen concentrations. If the concentration of dissolved oxygen in the discharging ground water is less than optimal, the trout may construct the redds in an area where there is less ground-water discharge and therefore, a less favorable temperature regime (Meisner and others, 1988).

Water temperature affects the concentration of dissolved oxygen because oxygen solubility varies inversely with temperature. Other factors being equal, warm water will have less oxygen available to the developing eggs than cool water. Low concentrations of dissolved oxygen also may result from (1) low transfer rates between ground and surface waters as streambed interstices become filled with fine-grained sediments, (2) high rates of microbial oxidation of entrained organic matter, and (3) concentrations of dissolved and suspended substances that create a high chemical-oxygen demand.

Adequate measurement of the concentrations of dissolved oxygen in the intragranular water is needed because the water in the interstices may contain less oxygen than the water in the stream above the spawning environment (Hoffman and Scoppettone, 1988). Because these measurements are difficult to make accurately, the USEPA (1986) recommends that a dissolved-oxygen concentration of $11 \mathrm{mg} / \mathrm{L}$ in the water column will achieve an intragravel concentration of $8 \mathrm{mg} / \mathrm{L}$, which is required for embryo and larval development. During other salmonid life stages, a minimum dissolved-oxygen concentration of $8 \mathrm{mg} / \mathrm{L}$ is recommended for the water column to avoid a decrease in fishery productivity (U.S. Environmental Protection Agency, 1986).

The Quashnet River has a favorable trout-spawning habitat with dissolvedoxygen concentrations that are well within the range necessary to support migrating adults and nourish developing eggs and larvae within and downstream of the spawning reach (table 2, fig. 4b). Dissolved-oxygen concentrations increased downstream until maximum concentrations were attained in the spawning reach. The upstream concentrations were fairly constant and ranged from 7.8 to $8.4 \mathrm{mg} / \mathrm{L}$. In the spawning reach (Sites 3 and 4), dis- 
solved-oxygen concentrations ranged from 9.3 to $12.6 \mathrm{mg} / \mathrm{L}$. In general, higher dissolved-oxygen concentrations were measured during the autumn spawning season than during the summer (table 2 and fig. $4 \mathrm{~b}$ ). This variation is attributed to lower water temperatures in autumn than in summer. The median dissolved-oxygen concentration in $\mathbf{4 8}$ ground-water samples from Cape Cod in 1975-76 was $7 \mathrm{mg} / \mathrm{L}$ (Frimpter and Gay, 1979).

\section{Hydrogen-Ion Concentration}

Hydrogen-ion activity in water is measured as $\mathrm{pH}$--the negative log of the hydrogen-ion activity to base 10 . The $\mathrm{pH}$ of stream water can have an indirect effect on spawning success, growth, and survival of the trout; the availability of nutrients and the toxicity of trace elements and contaminants are altered by shifts in $\mathrm{pH}$. The biological productivity of waters is closely correlated to their ability to neutralize acid; productivity decreases in direct proportion to the degree that the buffering capacity of river water is exhausted (U.S. Environmental Protection Agency, 1972). Even within optimal ranges, the $\mathrm{pH}$ at any location along a stream should not vary by more than 2.0 units, and the total alkalinity of the stream water should not fall by more than 25 percent below the natural alkalinity to prevent depletion of the carbonate buffering capacity (U.S. Environmental Protection Agency, 1972). For these reasons, the minimum essential buffering capacity of the Quashnet River and the $\mathrm{pH}$ range that will be tolerated by the trout during their life cycle in the stream needed to be assessed.

Along the length of the Quashnet River, $\mathrm{pH}$ was fairly constant, though the upstream sites were commonly more acidic than the downstream sites, probably because the upstream sites derive surface water from Johns Pond and the cranberry bogs (table 2 and fig. 4c). During the autumn, the $\mathrm{pH}$ values upstream were in the range of 5.46 to 5.80 units. This range will support only small populations of a few species of fish and may be lethal to the eggs and larvae of sensitive fish (U.S. Environmental Protection Agency, 1972). In the spawning reach (Sites 3 and 4) during the autumn season, $\mathrm{pH}$ ranged from 5.96 to 6.38 units. The $\mathrm{pH}$ at the streamflow-gaging station (Site 5) was similar to that at the spawning sites, ranging from 6.08 to 6.33 units during the autumn. According to the USEPA (1972), this range should support healthy aquatic populations of varied species with some exceptions. The USEPA (1972) recommends, however, a pH range 6.5 to 8.5 units as a nearly maximum level of protection for freshwater aquatic organisms and all the $\mathrm{pH}$ measurements taken during the autumn sampling fall below this range. These $\mathrm{pH}$ values also fail to meet the Massachusetts Surface-Water Quality standards of 6.5 to 8.0 for Class B, the State's designated use of the Quashnet River for the protection and propagation of fish (Division of Water 
Pollution Control, 1988). During the summer, the $\mathrm{pH}$ values ranged from 6.64 to 7.55 units along the length of the stream; these values fall within the optimal ranges. The median $\mathrm{pH}$ for 202 analyses of ground water on Cape Cod (in 1975-76) was reported to be 6.1 by Frimpter and Gay (1979).

\section{Specific Conductance}

In contrast to the other water-quality constituents measured, specific conductance, an indicator of dissolved solids concentrations, varied significantly at the same site within the autumn sampling season (table 2 and fig. 4d). The measured values ranged temporally from 54 to $66 \mu \mathrm{S} / \mathrm{cm}$ during the autumn sampling season; however, during each time period, specific conductance did not vary significantly along the length of the stream. On June 29,1989 , the specific conductance ranged from 72 to $82 \mu \mathrm{S} / \mathrm{cm}$. The specific conductance of the water flowing from Johns Pond $(82 \mu \mathrm{S} / \mathrm{cm})$ was essentially identical to the values measured by McVoy (1982) in the summer of 1978 at the same site. In general, the specific conductance of Johns Pond is higher than that of the ground water reported from two test wells (52 and $72 \mu \mathrm{S} / \mathrm{cm}$ ) in the watershed (T4 and P1 in fig. 1). Similarly, the cranberry bogs and other surface-water bodies have higher specific conductance $(67 \mu \mathrm{S} / \mathrm{cm})$ than the ground water. The low specific conductance of the ground water attests to its current uncontaminated condition.

\section{NEED FOR FUTURE STUDY}

Increased development in the Quashnet River basin has the potential to adversely affect the quantity and quality of streamflow in the river, possibly leading to a deterioration in the stream's capacity to support a reproducing trout population. Increased development may put stress on the Quashnet River for two reasons. First, increased withdrawals of ground water from the basin to meet growing demands may decrease the rates of ground-water discharge to the stream. Decreased rates of ground-water discharge could alter the temperature and dissolved-oxygen concentration of the intragravel water that bathes the trout eggs during development. Second, increased use of agricultural chemicals and discharge of septic system wastewater in the basin could degrade the quality of ground water that discharges through the streambed.

An immediate threat to the trout habitat of the Quashnet River appears to be the potential for decreases in rates of ground-water discharge to the river caused by increases in rates of ground-water withdrawals. In order to ensure the continued viability of the fishery, the effects of any proposed addi- 
tional ground-water withdrawals need to be assessed in terms of the location and amount of reduction of ground-water discharge to the different reaches of the Quashnet River. One approach to assessing these affects is to develop a calibrated digital model of ground-water flow and groundwater/stream interaction. Such a model could be used to identify (1) zones that contribute water to the wells, and (2) recharge areas that sustain ground-water discharge to the spawning reach. Land-use controls, such as controls on sewage disposal and pesticide and fertilizer use, could be applied to these identified areas to protect the fishery and water supplies. This model could also aid in selecting well locations and withdrawal rates to minimize the effect of ground-water withdrawals on the spawning reaches of the river. The ground-water and stream interaction model also could be used to simulate the changes in the water table and zone of contribution to the spawning reaches of the river under a variety of proposed withdrawal locations and withdrawal rates.

A better understanding of the existing physical and chemical conditions of the spawning reaches also is needed. Measurement of rate and quality of ground-water discharge at sites between the fish ladder (Site 3) and the streamflow-gaging station (Site 5) would aid in the calibration of the model described above. Measurements of the temporal and spatial distributions of temperature, $\mathrm{pH}$, specific conductance, and dissolved-oxygen concentrations in the intragravel microenvironment, where the eggs and larvae develop, would be useful in assessing the current status of egg development, newly hatched larvae, normal growth and activity, and overall fish production in the Quashnet River.

Development of a digital model of the Quashnet River basin will require the interpretation of available lithologic logs in order to gain an understanding of the three-dimensional framework and water-bearing characteristics of the ground-water flow system that contributes water to the river. Measurement of water levels in accessible wells in the study area would allow construction of a water-table map of the basin that will help delineate recharge areas that sustain ground-water discharge to the river and calibrate the digital model.

The results of such investigations could become an example of applied hydrology to fish habitat management for other coastal areas as well as the Quashnet River. Research on the intragravel microenvironment would provide fish-management biologists with information that, if applied to other streams, could be used to take advantage of natural ground-water discharge and thereby improve existing spawning areas and enable the creation of new fisheries. In addition to hydrologic investigations, the Quashnet River provides an opportunity for fish-management biologists to investigate 
thresholds of water velocity and depth, as well as the water-quality criteria necessary to sustain a trout fishery.

\section{SUMMARY AND CONCLUSIONS}

This report presents the results of a reconnaissance study of the physical and water-quality characteristics of the Quashnet River. Stream width, depth, cross-sectional area, velocity, and discharge were obtained at five sites; temperature, dissolved-oxygen concentration, $\mathrm{pH}$, and specific conductance were measured concurrently.

The annual autumn spawning run of sea-run brown trout was found to coincide with the release of water from a cranberry bog following harvest. During the 2-day interval when spawning activity peaked, velocities reached $1.8 \mathrm{ft} / \mathrm{s}$ and the discharge peaked at $32 \mathrm{ft}^{3} / \mathrm{s}$ at the center of the spawning area. The river is normally sustained by ground-water discharge at all but the highest flow rates. During base flow, when all of the streamflow is from storage, about one-third of the streamflow below the spawning reach is derived from ground-water discharge in the spawning reach.

In the spawning reach, during the spawning period, temperatures ranged from 10 to $11^{\circ} \mathrm{C}$, dissolved-oxygen concentrations ranged from 9.3 to $12.6 \mathrm{mg} / \mathrm{L}, \mathrm{pH}$ ranged from 5.96 to 6.38 units, and specific conductance ranged from 54 to $66 \mu \mathrm{S} / \mathrm{cm}$.

The hydrologic and water-quality information presented in this report establishes an initial data base for research on the interaction of hydrology and aquatic biology in an environment where fish-embryo development is directly affected by hydrologic and water-quality conditions. These data are useful in planning additional work addressing the effects of proposed ground-water withdrawals and potential water-quality degradation that can result from increased residential development in the watershed of the trout fishery.

\section{REFERENCES CITED}

Bliven, Steve, 1989, Coastal areas of critical environmental concern, Boston, Massachusetts: Massachusetts Coastal Zone Management Office, Publication No. 16,096-140-250-10-89-C.R., p. II32-39. 
Division of Water Pollution Control, 1988, Commonwealth of Massachusetts summary of water quality 1988, Appendix I- Massachusetts surface water quality standards, $11 \mathrm{p}$.

Frimpter, M. H. and Gay, F. B., 1979, Chemical quality of ground water on Cape Cod, Massachusetts: U.S. Geological Survey Water-Resources Investigations Report 79-65, 11 p.

Guswa, J. H. and LeBlanc, D. R., 1985, Digital models of ground-water flow in the Cape Cod Aquifer System, Massachusetts: U.S. Geological Survey Water-Supply Paper 2209, 112 p.

Hoffman, R. J. and Scoppettone, G. G., 1988, Effects of water quality on survival of Lahontan Cutthroat trout eggs in the Truckee River, West-Central Nevada and Eastern California: U.S. Geological Survey Water-Supply Paper 2319, $21 \mathrm{p}$.

LeBlanc, D. R., Guswa, J. H., Frimpter, M. H. and Londquist, C. J., 1986, Ground-water resources of Cape Cod, Massachusetts: U.S. Geological Survey Hydrologic Investigations Atlas HA-692.

Leitritz, Earl, and Lewis, R.C., 1976, Trout and salmon culture (hatchery methods): Sacramento, Calif., California Department of Fish and Game, Fish Bulletin 164, $197 \mathrm{p}$.

McLarney, W., 1988, Onward and upward on the Quashnet: Journal of the Massachusetts Audubon Society, v. 27, no. 8, p. 12-14.

McVoy, R. S., 1982, Johns Pond 1978-1980 diagnostic/feasibility study: Dept. of Environmental Quality Engineering, Division of Water Pollution Control, Technical Services Branch, 159 p.

Meisner, J. D., Rosenfeld, J. S., and Rogier, H. A., 1988, The role of groundwater in the impact of climate warming on stream salmonines: Fisheries, v. 13, no. 3., p. 2-8.

Persky, J. H., 1986, The relation of ground-water quality to housing density, Cape Cod, Massachusetts: U.S. Geological Survey Water-Resources Investigations Report 86-4093, $28 \mathrm{p}$.

Rantz, S.E., and others, 1982, Measurement and computation of streamflow: v. 1. Measurement of stage and discharge: U.S. Geological Survey WaterSupply Paper 2175, 284 p.

Ryan, B. J., 1980, Cape Cod Aquifer, Cape Cod, Massachusetts: U.S. Geological Survey Water-Resources Investigations Report 80-571, 23 p. 
Strahler, A. N., 1972, The environmental impact of ground water use on Cape Cod: Orleans, Massachusetts, Association for the Preservation of Cape Cod, Impact Study III, 68 p.

U.S. Department of Commerce, 1988-89, Monthly climatological data: Hatchville, Mass.

U.S. Environmental Protection Agency, 1986, Quality criteria for water 1986: EPA 440/5-86-001, U.S. Government Printing Office, Washington, D.C.

U.S. Environmental Protection Agency, 1972, Water quality criteria 1972: EPA-R3-73-033, U.S. Government Printing Office, Washington, D.C., $594 \mathrm{p}$. 